\title{
Risk of dyslipidemia among children undergoing routine medical examinations in a secondary health care facility in Benin City, Edo State
}

\author{
Izehiuwa G. Enato, ${ }^{1}$ Kingsley I. Akhimienho, ${ }^{1}$ Kenneth Atoe ${ }^{2,3,4}$ \\ ${ }^{1}$ Department of Paediatrics; ${ }^{2}$ Department of Chemical Pathology, Edo State University, Uzairue; \\ ${ }^{3}$ Phytomedicine and Drug Discovery Unit, Department of Plant Biology and Biotechnology; \\ ${ }^{4}$ Applied Environmental Bioscience and Public Research Group, University of Benin, Benin City, Nigeria
}

\begin{abstract}
Dyslipidemias in children are a diverse group of disorders that include monogenic disorders as well as dyslipidemias caused by a variety of factors. Although cholesterol levels in healthy children differ with age, a potential link to the development of dyslipidemia may be important to determine the likelihood of an early diagnosis. In this cross-sectional study, 220 seemingly healthy children aged 1 to 12 years were studied in Benin City, Nigeria, to determine the pattern of lipid profile. An enzymatic method was used to analyze serum lipids from blood samples obtained from the participants. The level of dispersion of data needed to assess the risk of early childhood dyslipidemia was described using the 95th percentile scale. In the 1-3 years old age group, at least 95 percent of the boys had total cholesterol levels below $132 \mathrm{mg} / \mathrm{dL}$, compared to 124
\end{abstract}

Correspondence: Kenneth Atoe, Department of Chemical Pathology, Edo State University, Uzairue.

E-mail: atoe.kenneth@edouniversity.edu.ng

Key words: Dyslipidemia; cholesterol; triglyceride; BMI; blood pressure.

Conflict of interests: The authors declare no conflict of interest.

Availability of data and materials: All data generated or analyzed during this study are included in this published article.

Ethics approval and consent to participate: The Ethics Committee of Edo State Ministry of Health approved this study (Reference: HA$737 / 42$, dated 3rd June, 2020). The study is conformed with the Helsinki Declaration of 1964, as revised in 2013, concerning human and animal rights.

Consent for publication: Written informed consent was obtained from a legally authorized representative(s) for anonymized patient information to be published in this article.

Received for publication: 4 March 2021.

Revision received: 27 March 2021.

Accepted for publication: 2 April 2021.

This work is licensed under a Creative Commons Attribution NonCommercial 4.0 License (CC BY-NC 4.0).

${ }^{\circ}$ Copyright: the Author(s), 2021

Licensee PAGEPress, Italy

Annals of Clinical and Biomedical Research 2021; 2:138

doi:10.4081/acbr.2021.138 $\mathrm{mg} / \mathrm{dL}$ among the girls of the same age. Similarly, total cholesterol levels in the 7-9 year old age group were $127 \mathrm{mg} / \mathrm{dL}$ in boys and $110 \mathrm{mg} / \mathrm{dL}$ in girls. These levels could serve as a guideline for children of the study's age group who appear to be in good health. Elevated triglycerides levels were found in male children under the age of three years, as well as in the 10-12 age brackets. Increases in triglycerides in the girls, on the other hand, were not age- or time-dependent. In general, the lipid profiles shown in the results were low, particularly in the 4-6 year old age group. A significant modifiable risk factor for cardiovascular disease in children is elevated lipid levels. The results of this study demonstrate the importance of routinely screening children for dyslipidemia. Elevated lipid levels are a major modifiable risk factor for cardiovascular disease in children. The findings of this research can be used as a basis for screening children for dyslipidemia because it provides a $95^{\text {th }}$ percentile in lipid profiles of seemingly healthy children.

\section{Introduction}

Dyslipidaemia is becoming a major public health issue around the world. Despite the fact that it is a preventable significant risk factor for coronary heart disease, it is the eighth leading cause of death in Nigeria. ${ }^{1}$ Previously, dyslipidaemia was thought to be rare among black people in comparison to the rest of the world, but recent studies indicate that it is extremely common in Nigeria, with a consistent trend of low high density lipoprotein cholesterol (HDL-C) and elevated low density lipoprotein cholesterol (LDLC) levels. ${ }^{2}$

This pathology has been established as a critical aetiological factor in cardiovascular disease growth. Cardiovascular disorders have been shown to start in children, and endothelial damage has been linked to lipid abnormalities in the first few years of existence. $^{3-5}$ Unhealthy eating habits, lack of physical activity, and abnormal weight gain have all been linked to dyslipidemia in children. ${ }^{6}$

Variations in serum lipid profile levels have been found in studies of children from various countries. ${ }^{7,8}$ These studies have indicated that before puberty, serum lipids have an age and geographical pattern of distribution. Furthermore, in developed countries, only a few laboratories have reference values for serum lipids in children. Serum lipid concentration and the risk of dyslipidaemia in children are not routinely tested in most Nigerian clinics. Given the role of dyslipidaemia in the development of cardiovascular diseases later in life, this is a dangerous pattern. The study's aim was to determine the trend of serum lipid profile levels among seemingly healthy children in Benin City in order to determine the risk of dyslipidemia. 


\section{Materials and Methods}

\section{Participants}

A cross-sectional analysis was conducted on 220 children who presented to the central hospital's paediatric out-patient department in Benin City. Many of the children who were enlisted seemed to be in good health and were between the ages of one and twelve. Those who had symptoms of a febrile condition, as well as diabetes, renal, or hepatic disease, were not allowed to participate in the study. With minimal clothing on, the participants' weights were assessed using a 6AA battery operated digital scale. A collapsible seca ${ }^{\circledR} 217$ standometer was also used to assess the participants' height. A seca ${ }^{\circledR} 416$ infantometer was used to measure the heights of children under the age of two. The waist circumference was calculated at the midpoint between the last palpable rib and the tip of the iliac crest with a flexible non-elastic tape (Seca ${ }^{\circledR 201)}$.

A venipuncture was performed, and approximately $2 \mathrm{~mL}$ of blood was collected into a plain tube. The entire blood was able to clot and retract before being centrifuged for 15 minutes at 3000 $\mathrm{rpm}$. With a Pasteur pipette, the serum was collected into $5 \mathrm{ml}$ plain tubes and stored at $-20^{\circ} \mathrm{C}$ before biochemical analysis was performed. The lipid analysis was carried out using an enzymatic approach, ${ }^{9}$ with reagents supplied by Randox Laboratory Limited and the standard operating assay technique used.

\section{Ethical clearance}

Ethical approval was obtained from the Edo State Ministry of Health (Reference: HA-737/42, dated $3^{\text {rd }}$ June, 2020).

\section{Statistical Analysis}

Results of this study were subjected to analyses of variance at a $95 \%$ confidence interval. The $95^{\text {th }}$ percentile was utilized to assess the risk of early childhood dyslipidemia. Bivariate correlation was employed to understudy relationship between lipid profiles and body weight characteristics. The SPSS version 21 software was used to perform statistical analyses.

\section{Results}

The anthropometric data of study population is presented (Table 1). Four different age categories were presented for both male and female genders. The boys and girls within the 10-12 years categories had body weights ranging from $30.3-33.9 \mathrm{~kg}$, compared to $11.5-14.6 \mathrm{~kg}$ in the 1-3 years age category. Generally, waist circumference ranged from 53.2-62.9 cm. Similarly, Mid Upper Arm Circumference (MUAC) was 12.9-19.4 cm. The BMI of the study participants were highly dispersed. The median value for boys was 14.5 and 14.7 for girls (Figure 1). The modal values for both gender were 14.5 and 12.00 respectively. No significant differences in systolic and diastolic Blood Pressure (bp) irrespective of age and gender among the study population (Figure 2).

Table 1. Anthropometric data of study population.

\begin{tabular}{lcccc} 
Gender & $\begin{array}{c}\text { Age category } \\
\text { (years) }\end{array}$ & $\begin{array}{c}\text { Weight } \\
(\mathrm{kg})\end{array}$ & $\begin{array}{c}\text { Waist circumference } \\
(\mathrm{cm})\end{array}$ & $\begin{array}{c}\text { MUAC } \\
(\mathrm{cm})\end{array}$ \\
Boys & $1-3$ & $11.5 \pm 2.5$ & $53.8 \pm 4.3$ & $13.2 \pm 1.3$ \\
& $4-6$ & $17.2 \pm 4.5$ & $58.5 \pm 3.7$ & $13.9 \pm 1.6$ \\
& $7-9$ & $22.3 \pm 4.8$ & $60.5 \pm 3.5$ & $14.2 \pm 5.1$ \\
& $10-12$ & $30.3 \pm 5.0$ & $62.3 \pm 4.6$ & $19.4 \pm 2.0$ \\
& p-value & $<0.001$ & 0.001 & 0.007 \\
Girls & $1-3$ & $14.6 \pm 7.9$ & $53.2 \pm 5.2$ & $12.9 \pm 6.3$ \\
& $4-6$ & $16.2 \pm 4.7$ & $58.7 \pm 2.4$ & $13.2 \pm 4.3$ \\
& $7-9$ & $23.5 \pm 6.9$ & $61.1 \pm 6.4$ & $14.0 \pm 5.2$ \\
& $10-12$ & $33.9 \pm 8.3$ & $62.9 \pm 4.6$ & $17.8 \pm 4.2$ \\
& p-value & $<0.001$ & 0.149 & 0.727 \\
\hline
\end{tabular}

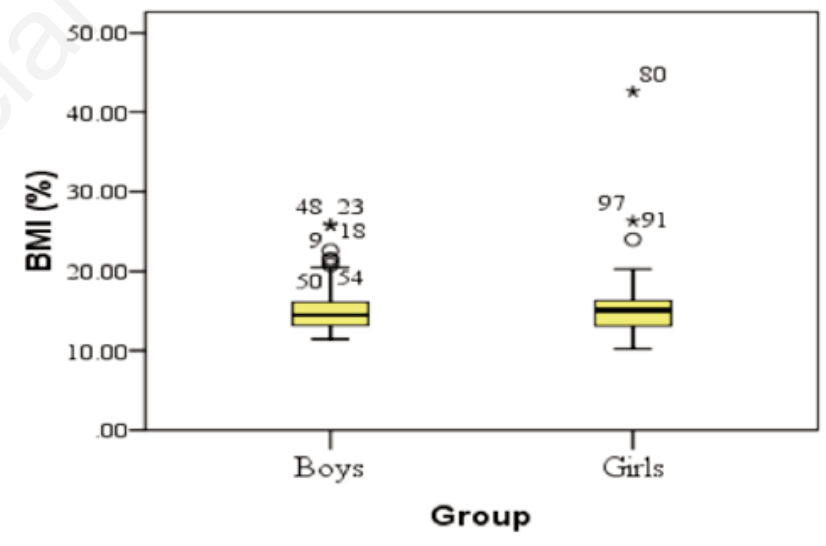

Figure 1. BMI of the study participants.

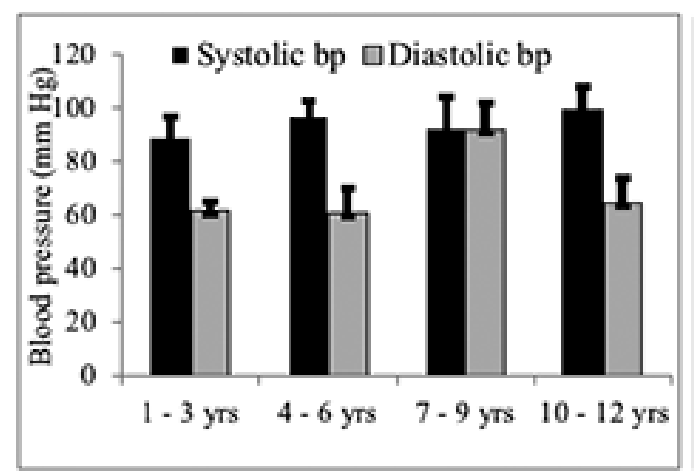

(a) Boys

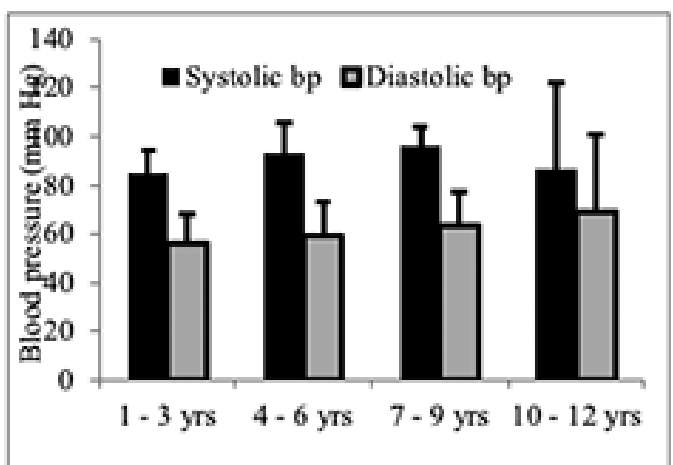

(b) Girls

Figure 2. Blood pressure data of the study population. 
Results showed that for the male child, significant increases in triglycerides were observed at periods below 3 years as well as in the 10-12 years category (Table 2). Whereas in the girl child, increases in triglycerides was not age- and time-dependent. Generally, lipid profiles as presented in the results, were at the least especially with the 4-6 years age bracket. Based on gender, bivariate correlation between systolic bp and waist circumference $(\mathrm{R}=$ $0.39, \mathrm{p}=0.003)$ and MUAC respectively $(\mathrm{R}=0.30, \mathrm{p}=0.027)$ among the boys as well among the girls (Table 3 ). Table 4 presents the bivariate correlation between BMI, waste circumference and mid-upper arm circumference on lipid profile and blood pressure of the respondents separated by age category. Significant positive correlation existed between BMI and systolic bp $(\mathrm{R}=0.49, \mathrm{p}=$ $0.018)$ as well as between BMI and diastolic bp $(\mathrm{R}=0.47, \mathrm{p}=$ 0.022 ) among the boys. Notably, significant correlation occurred between waste circumference and diastolic bp $(\mathrm{R}=0.38, \mathrm{p}=$ $0.016)$ among the boys. No observable correlation among analytes and blood pressure levels measured $(\mathrm{p}>0.05$ ).

The results of the $95^{\text {th }}$ percentile value for parameters measured for participants based on age category and gender has been presented. At least $95 \%$ of the boys in the study had total cholesterol levels within $132 \mathrm{mg} / \mathrm{dL}$ in the 1-3 years age category compared $124 \mathrm{mg} / \mathrm{dL}$ among the girls of same age. Similarly, total cholesterol within the 7-9 years age category was $127 \mathrm{mg} / \mathrm{dL}$ among the boys compared to $110 \mathrm{mg} / \mathrm{dL}$ for the girls (Table 5).

Significant distinctions in the distribution of lipid profiles as well as blood pressures among both genders were evidenced as provided by their chi-squared distribution $(\mathrm{p}<0.05)$ (Table 5). Going by their respective mean ranks, it was observed that total cholesterol for boys were relatively higher (rank 5.25) compared to those of the girls within the age brackets sampled (rank 3.75). Similarly, higher levels of HDL cholesterol were observed in the boys. However, higher levels of triglycerides, LDL cholesterol, NHDL cholesterol, VLDL cholesterol were observed in the girls than in the boys. No distinction in systolic bp between the two genders was observed.

\section{Discussion}

There are a variety of ways to assess a person's risk of dyslipidemia and atherosclerosis, even if they appear to be in good health. The risk factors linked to lipid profiles are extremely significant. This research looked at the lipid profiles of seemingly healthy boys and girls (ages 1 to 12) with the goal of assessing lipid concentration, progression and its relationship with sex. In a previous study

Table 2. Serum lipid profile levels in the study population.

\begin{tabular}{|c|c|c|c|c|c|c|c|c|}
\hline Gender & Age (years) & (n) & Total cholesterol & Triglycerides & HDL cholesterol & LDL cholesterol & NHDL cholesterol & VLDL \\
\hline Boys & $\begin{array}{c}1-3 \\
4-6 \\
7-9 \\
10-12 \\
\text { p-value }\end{array}$ & $\begin{array}{c}22 \\
12 \\
14 \\
7\end{array}$ & $\begin{array}{c}88.4 \pm 25.5 \\
69.8 \pm 25.7 \\
79.0 \pm 22.2 \\
87.3 \pm 25.1 \\
0.191\end{array}$ & $\begin{array}{c}70.8 \pm 23.9 \\
50.9 \pm 20.8 \\
58.2 \pm 19.9 \\
77.6 \pm 32.6 \\
0.044\end{array}$ & $\begin{array}{c}39.0 \pm 7.6 \\
34.2 \pm 8.4 \\
37.7 \pm 7.8 \\
40.0 \pm 9.6 \\
0.337\end{array}$ & $\begin{array}{c}34.8 \pm 16.6 \\
25.1 \pm 16.5 \\
28.9 \pm 13.1 \\
31.3 \pm 12.1 \\
0.345\end{array}$ & $\begin{array}{c}49.4 \pm 20.3 \\
35.7 \pm 18.8 \\
41.3 \pm 15.6 \\
47.3 \pm 17.4 \\
0.202\end{array}$ & $\begin{array}{c}14.2 \pm 4.8 \\
10.2 \pm 4.2 \\
11.6 \pm 4.0 \\
15.5 \pm 6.5 \\
0.044\end{array}$ \\
\hline Girls & $\begin{array}{c}1-3 \\
4-6 \\
7-9 \\
10-12 \\
\text { p-value }\end{array}$ & $\begin{array}{c}21 \\
15 \\
11 \\
8\end{array}$ & $\begin{array}{c}83.6 \pm 24.1 \\
69.8 \pm 25.3 \\
95.5 \pm 32.3 \\
75.6 \pm 19.2 \\
0.086\end{array}$ & $\begin{array}{c}68.1 \pm 23.4 \\
53.5 \pm 26.7 \\
81.5 \pm 41.5 \\
48.9 \pm 22.8 \\
0.043\end{array}$ & $\begin{array}{c}37.5 \pm 7.7 \\
32.8 \pm 9.3 \\
38.5 \pm 8.8 \\
36.5 \pm 3.8 \\
0.252\end{array}$ & $\begin{array}{c}32.1 \pm 13.9 \\
25.3 \pm 13.0 \\
40.1 \pm 19.2 \\
28.8 \pm 12.9 \\
0.097\end{array}$ & $\begin{array}{c}46.0 \pm 17.7 \\
37.0 \pm 17.8 \\
57.0 \pm 24.6 \\
39.1 \pm 17.0 \\
0.064\end{array}$ & $\begin{array}{c}13.6 \pm 4.7 \\
10.7 \pm 5.3 \\
16.3 \pm 8.3 \\
9.8 \pm 4.6 \\
0.043\end{array}$ \\
\hline
\end{tabular}

VLDL very low density lipoprotein.

Table 3. Bivariate correlation between BMI, waste circumference and mid-upper arm circumference on lipid profile and blood pressure of the respondents separated by gender.

\begin{tabular}{|c|c|c|c|c|c|c|c|c|c|}
\hline \multirow[t]{2}{*}{ Parameter } & & \multicolumn{4}{|c|}{ Boys } & \multicolumn{4}{|c|}{ Girls } \\
\hline & & age grp & BMI & Waist circ & MUAC & age grp & BMI & Waist circ & MUAC \\
\hline Total cholesterol & R & -0.073 & -0.046 & -0.163 & $\begin{array}{l}0.018 \\
0898\end{array}$ & -0.073 & -0.046 & $\begin{array}{l}-0.163 \\
0.724\end{array}$ & 0.018 \\
\hline \multirow{2}{*}{ Tryglyceride } & & -0.028 & 0.017 & -0.145 & 0.175 & -0.028 & 0.017 & -0.145 & 0.175 \\
\hline & p-value & 0.839 & $\begin{array}{c}0.9 \\
0.9\end{array}$ & $\begin{array}{l}-0.140 \\
0.29\end{array}$ & 0.202 & $\begin{array}{c}-0.020 \\
0.839\end{array}$ & $\begin{array}{c}0.011 \\
0.9\end{array}$ & $\begin{array}{c}-0.145 \\
0.29\end{array}$ & 0.202 \\
\hline \multirow[t]{2}{*}{ HDL Cholesterol } & $\mathrm{R}$ & 0.005 & 0.116 & -0.082 & 0.112 & 0.005 & 0.116 & -0.082 & 0.112 \\
\hline & $\mathrm{p}$-value & 0.971 & 0.398 & 0.552 & 0.416 & 0.971 & 0.398 & 0.552 & 0.416 \\
\hline \multirow[t]{2}{*}{ LDL Cholesterol } & $\mathrm{R}$ & -0.12 & -0.146 & -0.18 & -0.094 & -0.12 & -0.146 & -0.18 & -0.094 \\
\hline & $\mathrm{p}$-value & 0.385 & 0.286 & 0.188 & 0.495 & 0.385 & 0.286 & 0.188 & 0.495 \\
\hline \multirow[t]{2}{*}{ NHDL Cholesterol } & $\mathrm{R}$ & -0.1 & -0.112 & -0.182 & -0.025 & -0.1 & -0.112 & -0.182 & -0.025 \\
\hline & p-value & 0.467 & 0.415 & 0.183 & 0.858 & 0.467 & 0.415 & 0.183 & 0.858 \\
\hline \multirow[t]{2}{*}{ VLDL Cholesterol } & $\mathrm{R}$ & -0.028 & 0.017 & -0.145 & 0.175 & -0.028 & 0.017 & -0.145 & 0.175 \\
\hline & p-value & 0.839 & 0.9 & 0.29 & 0.202 & 0.839 & 0.9 & 0.29 & 0.202 \\
\hline \multirow[t]{2}{*}{ Systolic bp } & & $0.320^{*}$ & 0.05 & $0.388^{*}$ & $0.297^{*}$ & $0.320^{*}$ & 0.05 & $0.388^{*}$ & $0.297^{*}$ \\
\hline & p-value & 0.017 & 0.718 & 0.003 & 0.027 & 0.017 & 0.718 & 0.003 & 0.027 \\
\hline \multirow[t]{2}{*}{ Diastolic Bp } & $\mathrm{R}$ & 0.083 & -0.007 & $0.293^{*}$ & 0.103 & 0.083 & -0.007 & $0.293^{*}$ & 0.103 \\
\hline & p-value & 0.548 & 0.96 & 0.03 & 0.452 & 0.548 & 0.96 & 0.03 & 0.452 \\
\hline
\end{tabular}

** Correlation is significant at the 0.01 level (2-tailed). ${ }^{*}$ Correlation is significant at the 0.05 level (2-tailed). 
of Nigerian children under the age of five, Akuyam et al. found that serum total cholesterol levels decreased with age, with a greater decrease between the first and second years of life. ${ }^{10}$ In the current study, however, there were no significant differences in TC between the sexes as age progressed from 1 to 12 years. Shawar et $a l .{ }^{11}$ found a relatively high prevalence of hypercholesterolemia among young university students aged 16 to 30 at Arabian Gulf University. They reported that factors such as obesity, a fatty diet, and the epigenetics of their subjects may have led to the early hypercholesterolemia found by Shawar et al. ${ }^{11}$ In the present study, however, obesity as a risk factor for dyslipidemia in children was minimal $(\mathrm{p}>0.05)$.

Tables with age and gender-based percentiles for serum lipid profile levels in seemingly stable children on regular check-up visits in a secondary health facility are provided in this report. The current study found that blood lipid components differed by gender within specific age group, with the highest level occurring between the ages of 7 and 12. The total cholesterol levels of male children were higher than those of female children in the same age groups. Furthermore, the boys had higher HDL cholesterol levels. Triglycerides, LDL cholesterol, NHDL cholesterol, and VLDL cholesterol were all higher in the girls than in the boys. In a related study, Martinez et al. ${ }^{12}$ found that Total cholesterol, High Density Lipoprotein-Cholesterol, and Low Density LipoproteinCholesterol levels did not vary significantly by sex until children were 12 years old. In puberty, however, they were substantially higher in girls than in boys. Triglycerides and Very Low Density Lipoprotein-Cholesterol levels, on the other hand, were higher in girls than in boys until they were 12 years old, after which there was no difference.

Although there was no significant link between lipid profiles and blood pressure in this study, Armstrong et al. ${ }^{13}$ found a link between a poor lipid profile and an increase in blood pressure, particularly when combined with other risk factors, conditions that favor the development of atherosclerosis in children. Patterns of change in blood lipid components with age differ significantly among gender and racial groups, according to Dai et al. ${ }^{14}$ Increased body fatness in children is found to be linked with a rise in blood lipid levels. Blood lipid levels should be assessed taking into account differences in age, gender, and race.

The key drawback of this research was that it took longer to achieve the sample population of 220 participants, owing to most parents' refusal to volunteer permission for their children to be included in the study.

Table 4. Bivariate correlation between BMI, waste circumference and mid-upper arm circumference on lipid profile and blood pressure of the respondents separated by age category.

\begin{tabular}{|c|c|c|c|c|c|c|c|c|c|c|c|c|}
\hline & BMI & $\begin{array}{l}\text { 1-3 years } \\
\text { Waist_circ }\end{array}$ & MUAC & $\begin{array}{c}\text { 4-6 years } \\
\text { BMI }\end{array}$ & Waist_circ & $\begin{array}{l}\text { 7-9 years } \\
\text { MUAC }\end{array}$ & BMI & $\begin{array}{l}\text { 10-12 years } \\
\text { Waist_circ }\end{array}$ & MUAC & BMI & Waist_circ & MUA \\
\hline $\begin{array}{c}R \\
\text { p-value }\end{array}$ & $\begin{array}{l}-0.002 \\
0.988\end{array}$ & $\begin{array}{l}-0.159 \\
0.333\end{array}$ & $\begin{array}{l}-0.172 \\
0.294\end{array}$ & $\begin{array}{l}-0.205 \\
0.349\end{array}$ & $\begin{array}{r}-0.235 \\
0.281\end{array}$ & $\begin{array}{l}0.009 \\
0.968\end{array}$ & $\begin{array}{l}-0.162 \\
0.449\end{array}$ & $\begin{array}{l}0.073 \\
0.733\end{array}$ & $\begin{array}{l}-0.116 \\
0.591\end{array}$ & $\begin{array}{l}0.062 \\
0.834\end{array}$ & $\begin{array}{l}0.343 \\
0.231\end{array}$ & $\begin{array}{l}0.299 \\
0.299\end{array}$ \\
\hline $\begin{array}{c}R \\
\text { p-value }\end{array}$ & $\begin{array}{l}0.041 \\
0.802\end{array}$ & $\begin{array}{l}-0.262 \\
0.107\end{array}$ & $\begin{array}{l}-0.186 \\
0.257\end{array}$ & $\begin{array}{r}-0.117 \\
0.595\end{array}$ & $\begin{array}{c}-0.192 \\
0.38\end{array}$ & $\begin{array}{l}0.11 \\
0.616\end{array}$ & $\begin{array}{l}-0.229 \\
0.282\end{array}$ & $\begin{array}{l}0.072 \\
0.738\end{array}$ & $\begin{array}{r}-0.077 \\
0.720\end{array}$ & $\begin{array}{l}0.073 \\
0.803\end{array}$ & $\begin{array}{l}0.301 \\
0.296\end{array}$ & $\begin{array}{l}0.277 \\
0.338\end{array}$ \\
\hline $\begin{array}{l}\text { HDL_Chol R } \\
\text { p-value }\end{array}$ & $\begin{array}{l}0.112 \\
0.497\end{array}$ & $\begin{array}{c}-0.025 \\
0.88\end{array}$ & $\begin{array}{l}0.02 \\
0.905\end{array}$ & $\begin{array}{c}-0.066 \\
0.765\end{array}$ & & & $\begin{array}{l}-0.102 \\
0.635\end{array}$ & $\begin{array}{l}0.139 \\
0.518\end{array}$ & & $\begin{array}{l}0.148 \\
0.614\end{array}$ & & $\begin{array}{l}0.132 \\
0.653\end{array}$ \\
\hline $\begin{array}{l}\text { LDL_Chol R R } \\
\text { p-value }\end{array}$ & $\begin{array}{c}-0.071 \\
0.669\end{array}$ & $\begin{array}{l}-0.162 \\
0.324\end{array}$ & $\begin{array}{l}-0.23 \\
0.158\end{array}$ & $\begin{array}{r}-0.275 \\
0.204\end{array}$ & $\begin{array}{r}-0.245 \\
0.261\end{array}$ & $\begin{array}{c}-0.101 \\
0.647\end{array}$ & $\begin{array}{c}-0.141 \\
0.511\end{array}$ & $\begin{array}{c}-0.013 \\
0.953\end{array}$ & & $\begin{array}{c}-0.019 \\
0.947\end{array}$ & $\begin{array}{l}0.407 \\
0.148\end{array}$ & $\begin{array}{l}0.318 \\
0.267\end{array}$ \\
\hline $\begin{array}{r}\text { NHDL_Chol R } \\
\text { p-value }\end{array}$ & $\begin{array}{l}-0.049 \\
0.766\end{array}$ & $\begin{array}{c}-0.198 \\
0.226\end{array}$ & $\begin{array}{c}-0.234 \\
0.152\end{array}$ & $\begin{array}{c}-0.254 \\
0.243\end{array}$ & $\begin{array}{c}-0.263 \\
0.224\end{array}$ & $\begin{array}{c}-0.065 \\
0.769\end{array}$ & $\begin{array}{l}-0.174 \\
0.415\end{array}$ & $\begin{array}{l}0.044 \\
0.840\end{array}$ & $\begin{array}{l}-0.152 \\
0.478\end{array}$ & $\begin{array}{l}0.017 \\
0.955\end{array}$ & $\begin{array}{l}0.396 \\
0.161\end{array}$ & $\begin{array}{l}0.331 \\
0.248\end{array}$ \\
\hline $\begin{array}{l}\text { VLDL_Chol R } \\
\text { p-value }\end{array}$ & $\begin{array}{l}0.041 \\
0.802\end{array}$ & $\begin{array}{c}-0.262 \\
0.107\end{array}$ & $\begin{array}{c}-0.186 \\
0.257\end{array}$ & $\begin{array}{l}-0.117 \\
0.595\end{array}$ & $\begin{array}{c}-0.192 \\
0.38\end{array}$ & $\begin{array}{c}0.11 \\
0.616\end{array}$ & $\begin{array}{c}-0.229 \\
0.282\end{array}$ & $\begin{array}{l}0.072 \\
0.738\end{array}$ & $\begin{array}{r}-0.077 \\
0.720\end{array}$ & $\begin{array}{l}0.073 \\
0.803\end{array}$ & $\begin{array}{l}0.301 \\
0.296\end{array}$ & $\begin{array}{l}0.277 \\
0.338\end{array}$ \\
\hline $\begin{array}{cc}\text { Sys_bp } & \mathrm{R} \\
& \text { p-value }\end{array}$ & $\begin{array}{l}0.123 \\
0.456\end{array}$ & $\begin{array}{l}0.045 \\
0.787\end{array}$ & $\begin{array}{l}-0.075 \\
0.649\end{array}$ & $\begin{array}{l}0.489 * \\
0.018\end{array}$ & $\begin{array}{l}0.344 \\
0.108\end{array}$ & $\begin{array}{c}0.34 \\
0.112\end{array}$ & $\begin{array}{l}0.222 \\
0.298\end{array}$ & $\begin{array}{l}0.044 \\
0.838\end{array}$ & $\begin{array}{l}0.086 \\
0.691\end{array}$ & $\begin{array}{l}0.353 \\
0.216\end{array}$ & $\begin{array}{l}0.318 \\
0.269\end{array}$ & $\begin{array}{l}-0.025 \\
0.931\end{array}$ \\
\hline $\begin{array}{cc}\text { Dia_Bp } & \mathrm{R} \\
\mathrm{p} \text {-value } & \end{array}$ & $\begin{array}{l}0.035 \\
0.833\end{array}$ & $\begin{array}{c}0.383^{*} \\
0.016\end{array}$ & $\begin{array}{l}-0.028 \\
0.863\end{array}$ & $\begin{array}{c}0.474 * \\
0.022\end{array}$ & $\begin{array}{l}0.183 \\
0.403\end{array}$ & $\begin{array}{l}0.344 \\
0.108\end{array}$ & $\begin{array}{l}0.128 \\
0.551\end{array}$ & $\begin{array}{l}-0.108 \\
0.617\end{array}$ & $\begin{array}{l}0.101 \\
0.637\end{array}$ & $\begin{array}{l}0.349 \\
0.221\end{array}$ & $\begin{array}{l}0.294 \\
0.307\end{array}$ & $\begin{array}{c}-0.074 \\
0.801\end{array}$ \\
\hline
\end{tabular}

**Correlation is significant at the 0.01 level (2-tailed). ${ }^{*}$ Correlation is significant at the 0.05 level (2-tailed). BMI body mass index, Waist. Circ waist circumference, MUAC Mid under arm circumference.

Table $5.95^{\text {th }}$ percentile value for lipid profiles of participants based on age category and gender

\begin{tabular}{|c|c|c|c|c|c|c|c|c|c|c|c|c|c|}
\hline \multirow[b]{2}{*}{ Parameters } & \multicolumn{4}{|c|}{ Boys } & \multicolumn{4}{|c|}{ Girls } & \multicolumn{2}{|c|}{ Mean rank } & \multirow[t]{2}{*}{$\chi^{2}$} & \multirow[t]{2}{*}{ df } & \multirow[t]{2}{*}{ p-value } \\
\hline & $\begin{array}{c}1-3 \\
\text { (years) }\end{array}$ & 4-6 & $\begin{array}{c}7-9 \\
\text { (years) }\end{array}$ & $10-12$ & $1-3$ & $4-6$ & $7-9$ & $10-12$ & Boys & Girls & & & \\
\hline Total cholesterol & 132.0 & 126.0 & 127.0 & 121.0 & 124.0 & 119.0 & 157.0 & 110.0 & 5.25 & 3.75 & 0.75 & 1 & 0.391 \\
\hline Triglycerides & 109.3 & 95.0 & 103.0 & 126.0 & 108.0 & 110.0 & 149.0 & 81.0 & 4.25 & 4.75 & 0.08 & 1 & 0.773 \\
\hline HDL-Cholesterol & 48.0 & 46.0 & 58.0 & 58.0 & 50.0 & 49.0 & 51.0 & 43.0 & 5.00 & 4.00 & 0.34 & 1 & 0.562 \\
\hline LDL- Cholesterol & 68.1 & 69.0 & 48.0 & 47.0 & 54.0 & 52.0 & 82.0 & 50.0 & 4.00 & 5.00 & 0.33 & 1 & 0.565 \\
\hline NHDL- Cholesterol & 89.3 & 81.0 & 69.0 & 63.0 & 74.0 & 73.0 & 106.0 & 67.0 & 4.25 & 4.75 & 0.08 & 1 & 0.774 \\
\hline VLDL & 21.9 & 19.0 & 20.6 & 25.2 & 21.6 & 22.0 & 29.8 & 16.2 & 4.25 & 4.75 & 0.08 & 1 & 0.773 \\
\hline
\end{tabular}

VLDL very low density lipoprotein. 
5. Virkola K, Pesonem E, Akensblom HK, Siimes MA. Cholesterol and carotid artery wall in children and adolescents with familial hypercholesteronemia: a controlled study by ultrasound. Acta Pediatr 1997;86:1203-7.

The findings of this study have highlighted the importance of comprehensive routine dyslipidaemia screening among children. Regular screening will aid in determining the status and risk factors for dyslipidemia and atherosclerosis, allowing for early detection and treatment, and eventually lowering the risk of cardiovascular disease. Given the abundance of evidence in the literature connecting the incidence of dyslipidemia in children, it is imperative that children be screened early. As a result of providing a 95th percentile of lipid profiles of apparently healthy children, this may be used to test children for dyslipidemia.

\section{References}

1. WHO. World health statistics 2006. WHO Press, World Health Organization, Switzerland. 80p, 2006 (Accessed on March 10, 2015. Available from: https://www.who.int/gho/publications/world_health_statistics/whostat2006_erratareduce.pdf

2. Oguejiofor OC, Onwukwe CH, Odenigbo CU. Dyslipidemia in Nigeria: prevalence and pattern. Ann Afr Med 2012;11:197202.

3. McGill HC Jr, McMahan CA, ZieskE AW, et al. Effect of nonlipid risk factors on atherosclerosis in youths with a favourable lipoprotein profile. Circulation 2001;103:1546-50.

4. Kavey REW, Daniel SR, Laver RM, et al. American Heart Association on guidelines for primary prevention of atherosclerotic cardiovascular disease beginning in childhood. Circulation 2003;107:1562-6.

6. Hedly A, Ogden CL, Jhonson CL, et al. Prevalence of overweight and obesity amongst us childrean adolescents and adults, 1999-2002. JAMA 2004;291:2847-50.

7. Kaudman JT, Wertenbricks S, Van des H, et al. Screening for risk factors for chronic diseases in children form fifteen countries. Prev Med 1981;10:121-32.

8. Khalol A, Gupta S, Madam A, et al. Serum lipid profile norms in indian children. Indian Pediator 1995,32:1177-80.

9. Allain CC, Poon LS, Chan CSG, et al. Enzymatic determination of Total Serum Cholesterol. Clinical Chemistry1974;20:470-5.

10. Akuyam SA, Isah HS, Ogala WN. Evaluation of serum lipid profile of under-five Nigerian children. Ann Afr Med 2007;6:119-23.

11. Shawar SM, Al-Bati NA, Al-Mahameed A, et al. Hypercholesterolemia among apparently healthy university students. Oman Med J 2012;27:274-80.

12. Martínez DL, Pérez IP, Calvo MTM, et al. The Fuenlabrada study: lipids and lipoproteins in children and adolescents. An Esp Pediatr 1989;31:342-9.

13. Armstrong N, Balding J, Gentle P, Kirby B. Serum lipids and blood pressure in relation to age and sexual maturity. Ann Hum Biol 1992;19:477-87.

14. Dai S, Fulton JE, Harrist RB, Grunbaum JH, et al. Blood lipids in children: age-related patterns and association with body-fat indices: Project HeartBeat! Am J Prev Med 2009:37:S56-64. 